\title{
A Study on the Justiciability of Economic Law
}

\author{
Lei Jing \\ Tianjin University, Tianjin, 300072, China
}

Keywords: Economic Law; Justiciability; Problems; Countermeasures

\begin{abstract}
Economic law plays an important role in the development of social economy, the construction of social system and the stable operation of social economic market. However, based on the practical situation of the justiciability of Economic Law in China, the litigability of economic law is restricted by many factors in the development, and there are still many shortcomings and defects, so it is necessary to conduct in-depth analysis and research on the justiciability of economic law. Based on the author's learning and practical experience, this paper first analyzed the problems existing in the justiciability of economic law, and then put forward the corresponding countermeasures.
\end{abstract}

\section{Introduction}

Economic Law is not only an effective legal means for the state to exercise the right functional power, but also an important condition for the sustained and stable development of the social and economic market. However, through the practice, we can see that the litigation mechanism is not very perfect at the present stage in our country, which has caused serious obstruction to the concrete implementation of the Economic Law. If it lasts for a long time, it will not only cause serious interference to the implementation of Economic Law, but also affect the implementation of the state power in our country. Economic Law has been paid more and more attention at the present stage, but one of its serious problems is that the justiciability is not strong enough. From the concept of law justiciability, the justiciability of Economic Law is an attribute of Economic Law itself which can resolve economic disputes by judicial means. This kind of attribute itself does not have the defect and the perfect, but its realization lawsuit mechanism has the flaw and the perfect difference, and it can be said that the defects of the credibility of the Economic Law are the defects of the litigation mechanism of its realization. Therefore, in the course of the development of modern society, we should be aware of the existing problems of the justiciability of Economic Law, and take targeted measures to analyze it according to the actual situation to find out the reasons why it is not strong enough.

\section{Problems Existing in the Justiciability of Economic Law}

\subsection{Legal liability of Economic Law is unclear}

In the process of legislation, there are still many deficiencies in the regulation of legal liability in Economic Law. In particular, it is not clear how the subject of regulation and regulation in Economic Law should be investigated for legal liability, so that the Economic Law in the field of litigation is not strong. China is still in the process of transition from planned economy to market economy, and the planned economy is still in the leading position in the economic development of our country. The high concentration of power is the characteristic of planned economy and the biggest drawback of planned economy. The highly centralized power in the planned economy cannot be effectively restricted by laws and regulations, which directly leads to the phenomenon of power abuse. The relevant power holders are free to use their rights, which will make a serious imbalance in the relationship between rights and responsibilities, so the legal liability can not be effectively protected, and responsibility can not form a constraint on power. It makes the actionable nature of Economic Law unable to be effectively enhanced, and the legal liability in Economic Law is not clear. 


\subsection{Disputes in Economic Law cannot be litigated}

When the judicial organ of our country accepts the prosecution case, it is necessary to carry on a detailed investigation to the prosecution case first, and judge the accepting condition of the prosecution case according to the relevant law stipulation. If it meets the conditions of acceptance stipulated by law, the judicial organ must accept the prosecution case; if the prosecution case does not meet the conditions stipulated by the law, it cannot be accepted by the judicial organ. Disputes in Economic Law cannot be litigated because they are not actionable under the law, and another reason is that the relevant judicial organs believe that disputes in Economic Law should not be accepted. The non-litigation in the law is due to the fact that the relevant judicial organ does not have the power to deal with certain Economic Law disputes, and the law legislator does not give the judiciary such a power. The legislator of the law considered two aspects of Economic Law in formulating such legal provisions: On the one hand, some disputes in Economic Law are not suitable for judicial trial; on the other hand, some disputes in Economic Law fall within the scope of administration of administrative organs, and the powers of administration and judicature are separated, so the judiciary does not have the power to manage disputes in Economic Law that belong to the administrative organs. However, as for the category of disputes in Economic Law, which disputes in Economic Law are not suitable for the judicial organs to be tried, why, what is the standard, and where is the boundary of power between the administrative organs and the judicial organs? These matters are not clearly divided in the relevant laws and regulations, and each country has different plans for these matters. When the judiciary accepts the relevant Economic Law disputes, it is unable to define its own scope of acceptance.

\subsection{A party in a dispute of Economic Law is unwilling to bring a suit}

There are many ways to solve the disputes of Economic Law. The parties in the disputes of Economic Law do not have to apply the judicial organs for the settlement of litigation, but can also choose other ways to solve the disputes. However, some parties in Economic Law disputes are not willing to submit a complaint to the relevant judicial organs when they choose other ways to solve the Economic Law disputes effectively. Even if the parties have too many obstacles in the process of submitting Economic Law disputes to the judiciary, the justiciability in Economic Law will become a device, and it can only be a superficial form in Economic Law. Parties in Economic Law disputes are unwilling to bring an action before the judiciary, mainly because it takes too long, too many procedures and too high a fee to resolve disputes in Economic Law through the judiciary. In particular, in the course of judicial proceedings on disputes in Economic Law, the fees charged by the parties concerned are generally relatively high, and the amount claimed in many dispute cases is not as high as the trial costs. This leads to a reluctance on the part of the parties to choose this solution. In the disputes of Economic Law, most disputes involve the public interest, and many violations of Economic Law cause harm to the public interest or the interests of most people. Therefore, when a certain victim maintains his own rights and interests, he not only protects his own rights and interests, but also, to a certain extent, protects the rights and interests of other victims. There is a link to the maintenance of Economic Law rights and interests. The contiguous relationship is beneficial to the protection of the rights and interests of Economic Law, but also affects the settlement of disputes in Economic Law to a certain extent. The contiguous relationship is beneficial to the protection of the rights and interests of Economic Law, and it also affects the settlement of disputes in Economic Law to a certain extent. The dependence of many victims in the face of Economic Law disputes is caused by this connection. Each victim expects other victims to defend their rights and interests, submit a complaint to the judicial authorities, but they only wait for the outcome of the trial. This kind of joint and several ideology directly leads to that many parties are unwilling to bring suit in the disputes of Economic Law, so the role of actionable in Economic Law can not be given full play. 


\section{Measures to Solve the Problems of the Economic Law Justiciability}

\subsection{To regulate the procedure in the dispute of Economic Law}

In the process of litigation of disputes in Economic Law, the specific causes of disputes can be deeply analyzed and studied. Then, according to the specific illegal acts in the dispute, the administrative organ will first try the Economic Law dispute. If the administrative organ refuses to accept the dispute or violates the relevant handling regulations, the parties in Economic Law disputes can file further proceedings with the judicial organs to avoid confusion between the powers of the administrative organs and the judicial organs, in this way, the judicial organs can be given more powers in handling disputes of Economic Law, and the scope of examination of judicial organs in disputes of Economic Law can be expanded. As a result, the judiciary can not only examine the relevant government economic management departments in the process of administrative law enforcement, but also examine all economic subjects involved in the public interest in the operation of the economy. By regulating the proceedings in Economic Law disputes, the judiciary can also have sufficient independence and autonomy in adjudicating Economic Law disputes, and take severe penalties for violations in Economic Law disputes, such as: Those who impose economic penalties on individuals who violate the law shall bear criminal responsibility if the circumstances are serious; those enterprises or units that have violated the law shall be punished by revocation of relevant certificates, economic punishment and dissolution of enterprises or units; For illegal enterprises or units, we shall revoke relevant licenses, impose economic penalties, and dissolve enterprises or units. To a great extent, the standardization of the litigation procedure of Economic Law disputes can ensure the exertion of the actionable function of Economic Law.

\section{2 To make a clear division of legal liability in Economic Law}

According to the different nature of the economic subject, the legal responsibility of the different economic subject in the Economic Law is clarified. For example, the legal responsibilities of the managed economic subject include revocation of license, economic punishment, closure of business, rectification, etc. The main body of economic management must bear the legal responsibility of its own functions and powers held in the economic management, including modification of unreasonable economic objectives and tasks, deprivation of authority and authority in relevant management, and correction of unreasonable economic intervention. A clear division of legal responsibilities in Economic Law can effectively enhance the justiciability of Economic Law and protect the legitimate rights and interests of the parties in the course of litigation.

\subsection{To construct a perfect public prosecution system of Economic Law}

In the process of constructing a sound public prosecution system of Economic Law, it is necessary to make clear that all individuals, enterprises and organizations have the right to sue. If the victim of a dispute in Economic Law is unwilling or unable to file a lawsuit, the relevant procuratorial organ may bring a lawsuit on his behalf, and may also restrict the relevant economic subject's qualification for litigation, for example, litigation capacity, economic contradictions, to avoid some illegal behavior. Secondly, economic public interest litigation can be effectively defined, such as monopoly in the market economy, illegal money laundering, tax evasion, illegal purchase and sale of public resources, when we construct the public prosecution system of Economic Law, we can adopt the principle of proper regulation and put the burden of proof upside down, to simplify the procedure of judicial organs in handling disputes of Economic Law.

\section{Conclusions}

The justiciability of law is an essential criterion in the development of modern society. The justiciability of Economic Law is the basic attribute and basis of the existence of Economic Law. Economic Law is an essential part of the construction and implementation of the social basic law, which can involve various interests. Therefore, it is necessary to strengthen the justiciability of 
Economic Law from various aspects and angles, which can not only provide effective protection for the basic rights and interests of the people, but also promote the sustainable development of our country's social economy.

\section{References}

[1] Guo Xiaoxing, Xu Jingxiang. Discussion on the defects of Economic Law and its remedy[J]. Legal Exposition, 2016, (20): 244.

[2] Cheng Mingyue. On the strategy of realizing the justiciability of Economic Law[J]. Legal Exposition, 2015, (16): 277.

[3] Yan Huimin. Discussion on the tactics of realizing the actionable legislation of Economic Law of our country[J]. Legal System and Society, 2012, (25): 118-119.

[4] Qiu Tang. Discussing the justiciability of Economic Law[J]. Legal System and Society, 2011, (28): 100-101.

[5] Chen Rong, Shi Berlin.On the perfection of the justiciability of Economic Law from the angle of view of annulment of the economic court[J]. Financial Theory and Practice, 2010, (01): 125-128.

[6] Zhang Tongzhen. On the remedy of the deficiency of the justiciability of Economic Law[J]. Legal System and Society,2008, (35): 131.

[7] Qian Shuo. On the justiciability of Economic Law[J]. Journal of Taiyuan normal University (Social Science Edition), 2008, (35): 131. 